Beata ZAJĄC

Uniwersytet Jagielloński

beataza@yahoo.fr

\title{
JĘZYKOWE ŚRODKI DEPRECJACJI PRZECIWNIKA W DEBATACH TELEWIZYJNYCH MIĘDZY LIDERAMI PARTYJNYMI
}

ABSTRACT Language means of depreciation of an opponent in television debates between party leaders

The article raises the issue of rhetoric means used in Polish parliamentary campaigns, exemplified by the 2007 campaign. However only an extract of such electoral activities was taken into consideration, namely the televised debates between the party leaders. The basis of the analysis consists of three debates broadcasted in Polish Television between: Donald Tusk and Jarosław Kaczyński (12th October 2007), Donald Tusk and Aleksander Kwaśniewski (15th October 2007), Jarosław Kaczyński and Aleksander Kwaśniewski (7th October 2007). The author focused on the language operations carried out in order to depreciate the opponent in the context of the situation created by media debate. The most common acts of depreciation - both overt and concealable in many ways - their action mechanisms, as well as the defence methods against them were analyzled in the article.

Keywords: TV debate, election campaign, language

Słowa kluczowe: debata telewizyjna, kampania wyborcza, język

Tiniejszy artykuł podejmuje problem środków retorycznych wykorzystywanych 1 w polskich kampaniach parlamentarnych. Opisowi poddane zostaną działania propagandowe związane z prezentacją poszczególnych ugrupowań w mediach, a ści- 
ślej: wycinek tych działań, czyli debaty telewizyjne między liderami partyjnymi. Uwaga zostanie skoncentrowana na pewnym typie zabiegów językowych, a mianowicie środkach służących zdeprecjonowaniu przeciwnika. Przedstawione będą najczęściej stosowane akty deprecjacji - zarówno jawne, jak i o różnym stopniu ukrycia - mechanizmy ich działania, a także sposoby obrony przed nimi.

Materiał do analizy pochodzi z kampanii parlamentarnej z $2007 \mathrm{r}$.

Debaty telewizyjne stały się współcześnie jednym z ważniejszych elementów walki wyborczej. Organizuje się je przede wszystkim w kampaniach prezydenckich, kiedy dają możliwość bezpośredniego skonfrontowania kandydatów i ich programów. W kampaniach parlamentarnych mieliśmy wcześniej do czynienia raczej z dyskusjami, w których uczestniczyło wielu przedstawicieli różnych ugrupowań. Wybory do Sejmu i Senatu w 2007 r. pokazały jednak, że można wykorzystać debatę jeden na jeden także w kampanii parlamentarnej, czyniąc głównymi aktorami liderów najważniejszych ugrupowań. Dlatego warto na tym przykładzie przyjrzeć się możliwościom, jakie stwarza politykom wykorzystanie debaty w nowej sytuacji.

Wydaje się, że zarówno sami uczestnicy, jak i media przypisują tej formie prowadzenia kampanii szczególne znaczenie. Telewizja na długo przed samymi debatami zapowiadała je jako wydarzenia wyjątkowe. Komentowano okoliczności, jakie im towarzyszyły, zachowania polityków przed debatami, a wreszcie na różny sposób je reklamowano, chcąc przyciągnąć przed ekrany jak największą liczbę telewidzów przez wykreowanie odpowiednich oczekiwań odbiorczych. Owe zakładane oczekiwania mają przy tym wpływ zarówno na kształt debaty, jak i na zachowania uczestników (zarówno polityków, jak i moderujących dziennikarzy). Chodzi o to, by była ona przede wszystkim atrakcyjna i angażująca emocjonalnie dla odbiorców oraz spełniała kryteria „medialności”. Dorota Piontek, pisząc o debacie między politykami w kontekście tabloidyzacji mediów, zwraca uwagę, że debata jest postrzegana jako rozgrywka czy „mecz” między uczestnikami, a odbiorcy zadają sobie przede wszystkim pytanie, kto będzie górą i kto komu „dołoży”'. Uczestnicy muszą brać pod uwagę te oczekiwania i przynajmniej w jakimś stopniu się do nich dostosować. Pozwala to przypuszczać, że właśnie środki służące zdeprecjonowaniu przeciwnika będą jednym z najistotniejszych elementów przyjmowanych przez polityków strategii komunikacyjnych.

Podstawę analizy stanowią trzy debaty wyemitowane w Telewizji Polskiej: Donald Tusk - Jarosław Kaczyński (12 października 2007 r.), Donald Tusk - Aleksander Kwaśniewski (15 października 2007 r.), Jarosław Kaczyński - Aleksander Kwaśniewski (7 października 2007 r.). Miały one charakter dyskusji ,jeden na jeden” w obecności moderującego publicysty, a także innych dziennikarzy, którzy zadawali politykom pytania. Uczestniczyła w nich również publiczność, żywo reagująca na riposty dyskutantów. Wypowiedź każdego z uczestników musiała się zmieścić w narzuconych ramach czasowych.

Autorka analizuje debatę Jana Rokity i Andrzeja Leppera emitowaną w Radiu Zet 14 V 2004 r. prowadzoną przez Monikę Olejnik; owa debata, jej zdaniem, przyspieszyta proces przejmowania przez znakomita większość dziennikarzy politycznych podobnych standardów prowadzenia rozmów o polityce. D. Piontek, Tabloidyzacja dziennikarstwa, [w:] Polubić dziennikarstwo, red. S. Zakrzewski, Poznań 2009, s. 242. 
Warto zauważyć, że samo uczestnictwo w takiej debacie podnosi szanse kandydata, który może zaistnieć w opinii publicznej jako postać pierwszoplanowa, przywódca partii o dużym znaczeniu i dużych szansach wyborczych. Jeśli to właśnie on został wybrany do rozmowy, to znaczy, że jest kimś ważnym, a jego pozycja i możliwość wpływu na wydarzenia są niezaprzeczalne. Poza tym media nagłaśniają i reklamują takie debaty, nadając im charakter wydarzeń wyjątkowych, ważnych. Przez samo uczestnictwo w debacie rozmówca umiejscawia się więc w hierarchii ważności polityków. Przecież nie wszyscy liderzy brali w takim wydarzeniu udział. Przywódcy ugrupowań uznanych przez media za mniej znaczące po prostu nie zostali do debaty zaproszeni. Uczestnikom analizowanych debat udało się więc już na wstępie osiągnąć podstawowy cel - samą obecność w telewizji ${ }^{2}$.

Uczestnicy debaty jeden na jeden znajdują się w korzystniejszej sytuacji niż biorący udział w wieloosobowej dyskusji. Przede wszystkim uwaga widza nie rozprasza się na wypowiedzi wielu różnych podmiotów, może on skoncentrować się na wypowiedziach antagonistów. Nie muszą oni więc tak bardzo walczyć o uwagę, nie istnieje niebezpieczeństwo, że ich głosy zostaną zagłuszone przez inne i nie zostaną zauważone. To na nich z założenia koncentruje się uwaga widza, który włącza odbiornik po to, by wysłuchać właśnie tych dwóch polityków. Nad tym, aby obaj mieli równe szanse i by żaden z nich nie przejął całkowicie inicjatywy, w analizowanych debatach czuwał dziennikarz-moderator. Obaj uczestnicy mieli także przydzielony określony czas na swoją wypowiedź i na pytanie dla przeciwnika. Po przekroczeniu tego czasu wypowiedź była przerywana. Czasem uczestnicy próbowali negocjować przyznanie im większej ilości czasu, innym razem, zaznaczając swoją kurtuazję, oddawali go przeciwnikowi.

Najistotniejszym elementem debaty, choć nieobecnym bezpośrednio, wydaje się jednak publiczność przed telewizorami, która ma wydać osąd o sprawie i przyznać rację jednemu z rozmówców. Ma to istotny wpływ na przebieg sporu i argumentację, zmienia sposób dyskutowania. Zazwyczaj w przypadku dysputy przyjmuje się założenie, że chodzi o przekonanie partnera do swoich racji. Strategie retoryczne dobiera się więc pod kątem rozmówcy; to jego przekonania, system wartości, poziom intelektualny itd. decydują o doborze argumentów. Gdy celem jest rzeczywiste przekonanie partnera, istotne jest też wypracowanie z nim dobrej relacji. Brak zaufania czy niechęć spowodują, że zamknie się on na argumenty.

Debaty telewizyjne analizowane w niniejszym artykule prawie nigdy nie służą temu, by jeden z rozmówców uznał racje drugiego. Głównym celem jest przecież pozyskanie publiczności, zrobienie korzystnego wrażenia, a przez to wywarcie wpływu na poglądy odbiorców - przekonanie ich do swoich racji lub zniechęcenie do racji prezentowanych przez kogoś innego. Najczęściej chodzi więc nie o przekonanie, a o pokonanie rozmówcy: wykazanie, że jest się kimś od niego lepszym, mądrzejszym, lepiej znającym się na

Jak zauważa Marek Kochan, [...] w mediach liczy się tak zwany czas antenowy, czyli sama obecność w radiu czy telewizji. Kto jest obecny w mediach, jest zauważalny, ma lepsze wyniki w sondażach, a potem uzyskuje więcej gtosów w wyborach. M. Kochan, Pojedynek na stowa. Techniki erystyczne w publicznych sporach, Kraków 2005, s. 17. 
rzeczy. A nawet nie tyle wykazanie, że jest się lepszym, ile stworzenie takiego wrażenia. Dyskutanci staraja się przekazywać jakieś opinie, ale tak naprawdę nie ma to większego znaczenia: publiczność ogląda debate jak pojedynek bokserski. Liczy się tylko jedno: kto wypadt lepiej, kto kogo pokonat ${ }^{3}$.

Właściwym adresatem wypowiadanych kwestii jest więc nie rozmówca, ale maksymalnie szeroka publiczność. Debatujący chcą dotrzeć do największej liczby adresatów, co wpływa na wybór technik retorycznych, innych niż w przypadku rzeczywistego przekonywania interlokutora. Inaczej musi tu też być rozumiana jedna z podstawowych zasad retoryki: dostosuj kształt językowy wypowiedzi i typy argumentów do adresata. Wiedza o rozmówcy to podstawa skutecznego przekonywania. W przypadku debat telewizyjnych trudno nawet w przybliżeniu wyobrazić sobie wspólne cechy odbiorców, trzeba więc tak dobrać słowa i argumenty, by trafily do wszystkich. Najlepiej w takim razie byłoby się odwołać do uniwersalnych ludzkich dyspozycji, do powszechnych nastawień i oczekiwań, do podstawowych ludzkich potrzeb i potocznego obrazu świata. Wyrafinowany styl wypowiedzi, skomplikowana argumentacja muszą ustąpić miejsca zabiegom prostszym, ale w tej sytuacji bardziej skutecznym.

Prowadzi to uczestników w stronę argumentów raczej erystycznych niż retorycznych, a ponieważ „zwycięstwo” polega na zrobieniu jak najlepszego wrażenia i umniejszeniu przeciwnika, na pierwszy plan wysunie się pozytywna autoprezentacja oraz deprecjacja oponenta. Można zaryzykować tezę, że nawet wypowiedzi o pozornie innej intencji w kontekście opisywanych debat telewizyjnych zostaną podporządkowane tym właśnie celom.

Deprecjacja rozumiana jest zazwyczaj jako takie zachowanie językowe (i niejęzykowe), które ma na celu zagrożenie pozytywnemu wizerunkowi interlokutora, a szczególnie stanowi atak na jego pozytywnie zintegrowany obraz samego siebie ${ }^{4}$. Wiąże się to z doborem takich strategii językowych, dzięki którym nadawca może usytuować się w pozycji wyższościowej względem odbiorcy.

W debatach telewizyjnych obniżenie poczucia wartości interlokutora nie jest celem ostatecznym. Chodzi przede wszystkim o to, by obniżyć jego rangę w oczach widza. To on jest przecież właściwym adresatem padających w debacie replik. Mniej ważne jest, czy umniejszony poczuje się rozmówca, ważniejsze - czy widz postrzeże go jako umniejszonego. Atakowanie pozytywnego wizerunku przeciwnika w debacie pozwala jednak osiągnąć jeszcze inny efekt, może nie najważniejszy, ale przydatny. Można mianowicie wyprowadzić go z równowagi, zdenerwować, co daje atakującemu przewagę w sporze. Rozmówca traci wówczas kontrolę nad sobą, gubi się, zaczyna popełniać pomyłki. Sprowokowany, może także ripostować zbyt ostro i agresywnie, co z kolei może złamać spójność wizerunku, który sam stara się stworzyć, i w ten sposób zostają zniweczone wysiłki autoprezentacyjne. Żeby taki zabieg był skuteczny, nadawca musi uwzględnić żywą osobę o określonych poglądach, temperamencie i systemie wartości oraz zaatako-

\footnotetext{
Tamże, s. 21.
}

4 Por. M. Majewska, Akty deprecjonujące siebie i innych. Studium pragmalingwistyczne, Kraków 2005, s. 7, Pragmatyka i Semantyka Mowy. Studia i Analizy, 5. 
wać te sfery, które dla rozmówcy są ważne. Im lepiej zna się słabe punkty interlokutora, tym większa szansa, że prowokacja się powiedzie.

Zdeprecjonowanie przeciwnika może się odbywać za pomocą wielu zabiegów językowych. Może je cechować różny stopień bezpośredniości i niejednakowe nasilenie agresji. Pojawiają się więc z jednej strony akty deprecjacji jawne i niemal jednoznaczne w zamiarze obrażenia, a z drugiej - wypowiedzi zawoalowane, o ukrytej intencji, które trzeba dopiero rozszyfrować. Wypowiedzi w rzeczywistości deprecjonujące mogą nawet udawać pochwałę. Także nasilenie ataku może być różne: od delikatnych uszczypliwości po brutalną agresję. Napaść językowa może mieć różne formy. To, czy będzie ona skuteczna, zależy nie tylko od intencji nadawcy, rodzaju użytych środków językowych, będacych narzędziem walki, ale też od indywidualnego progu wrażliwości uczestników aktu komunikacji, ich kompetencji jezykowej, kontekstu lub konsytuacji5.

Najprostszą metodą zaatakowania przeciwnika jest wykorzystanie ostrych, obraźliwych i znieważających słów, czyli inwektyw i wyzwisk. Składnikiem inwektywy jest pewien sąd negatywny dotyczący odbiorcy, choć czasem sąd ten może sprowadzić się tylko do emocjonalnego epitetu lub wypowiedzenia wyzwiska ${ }^{6}$. Badacze języka polityki zgodnie zauważają, że zachowania obelżywe weszły już na stałe do repertuaru publicznych zachowań językowych. Granica między ,językiem parlamentarnym” a potocznością uległa zatarciu, co pociągnęło za sobą większą swobodę w wyrażaniu negatywnych emocji. Aby przeforsować swe stanowisko, wszystkie środki sa dozwolone. [...] absolutna nowościa jest nasycenie jezyka najnowszych tekstów politycznych inwektywami, zniewagami, obelgami. [...] Obrazić może każdy każdego, obrazić można wszystkich ${ }^{7}$.

Okazuje się jednak, że bezpośrednie obelgi nie są najbardziej skuteczne (albo skuteczne tylko wobec pewnego typu odbiorcy). Paradoksalnie najbardziej bezpośrednie, agresywne akty słowne nie są najbardziej udanymi aktami umniejszenia. Dlatego, że akty deprecjacji należą do tego typu dziatań jezzykowych, których intencja nie do końca powinna być rozszyfrowana, tylko zawoalowana. Odkrycie intencjonalności deprecjacji tak naprawdę może spowodować nieskuteczność tego aktu, gdyż może zaświadczyć o rzeczywistym stosunku nadawcy do odbiorcy ${ }^{8}$. Jawne przyznanie się do intencji obrażenia zwraca uwage na zamiar nadawcy i w pewnym sensie odbiera wagę stawianym zarzutom. Poza tym dokonując aktu zbyt jawnej deprecjacji, nadawca ryzykuje własny wizerunek, narażając się na opinię człowieka niegrzecznego, agresywnego i nieopanowanego. A w debacie, w której chodzi o pokazanie się z jak najlepszej strony, jest to ryzyko poważne. Zarzut agresji jest przy tym jednym z najczęściej stawianych językowi polityki i wpływa (obok innych zarzutów) na negatywny publiczny obraz wypowiedzi politycznych, rzutujący na obraz środowisk politycznych w ogóle. $W$ spotecznym postrzeganiu dziatań jezyko-

M. Peisert, Formy i funkcje agresji werbalnej. Próba typologii, Wrocław 2004, s. 39-40, Acta Universitatis Wratislaviensis, nr 2580.

6 Por. R. Grzegorczykowa, Obelga jako akt mowy, „Poradnik Językowy” 1991, nr 5-6, s. 193.

7 E. Kołodziejek, Językowe środki zwalczania przeciwnika, czyli o inwektywach we wspótczesnych tekstach politycznych, [w:] Jezzk polityki a wspótczesna kultura polityczna, red. J. Anusiewicz, B. Siciński, Wrocław 1994, s. 69-70, Jezyk a Kultura, t. 11.

$8 \quad$ M. Majewska, dz. cyt., s. 16-17. 
wych klasy politycznej dominuje prezentacja negatywna - podobnie zreszta jak w postrzeganiu catej tej klasy ${ }^{9}$. Niektórzy badacze uważają wręcz, że tu należy szukać przyczyn zniechęcenia do polityki, wyrażającego się m.in. niską frekwencją w wyborach.

Coraz więcej polityków zdaje sobie ze wspomnianych niebezpieczeństw sprawę, więc rzadziej decyduje się na obrażanie przeciwnika i obrzucanie go inwektywami. Do tego grona zdają się należeć uczestnicy opisywanych debat. Stosują oni raczej taktykę wypowiedzi pozornie wyważonych, neutralnych, w których deprecjacja jest na różne sposoby zawoalowana.

W analizowanym materiale bezpośrednie agresywne ataki na osobę przy użyciu inwektyw się nie pojawiają. Jeśli się ich używa (jest to bardzo rzadkie), to nie w stosunku do samego interlokutora, ale do kogoś, kto jest z nim jakoś powiązany, utożsamiany $\mathrm{z}$ nim. Ponadto nadawca zabezpiecza się na różne sposoby przed posądzeniem go o stosowanie tak negatywnie ocenianego środka. Zabezpieczeniu takiemu posłużyć może na przykład cytat. Charakterystyczna jest tu wypowiedź Donalda Tuska, który w debacie z Jarosławem Kaczyńskim tak ocenia politykę zagraniczną poprzedniego rządu: Polityka zagraniczna rzadu Jarostawa Kaczyńskiego zostata najokrutniej zdefiniowana czy zrecenzowana przez profesora Wtadystawa Bartoszewskiego. Ja bym wtaściwie nie odważyt się użyć tego sformutowania, ale ponieważ użyt tego sformutowania chyba największy żyjacy autorytet $w$ dziedzinie polityki zagranicznej, to odważe sie je powtórzyć: dyplomatotki.

Nadawca prezentuje się tutaj jako osoba kulturalna, która zna reguły grzeczności i wie, że bezpośrednie użycie cytowanego słowa jest nietaktowne. Przywołuje więc jego autora, ukrywając się niejako za jego autorytetem, który dla wzmocnienia zabezpieczenia został dodatkowo podkreślony. W ten sposób odpowiedzialność za mocne słowo została przerzucona na autora cytatu.

Innym przykładem zabezpieczenia, kiedy w nacechowanych emocjonalnie słowach przypisuje się rozmówcy negatywne charakterystyki, jest kolejna wypowiedź Tuska adresowana do Kaczyńskiego: Pan dzisiaj, Panie Jarostawie, nie jest symbolem dialogu $z$ grupami spotecznymi, wręcz pańska wtadza stata się symbolem buty $i$ arogancji wobec najstabszych grup. Nadawca nie używa tu najprostszej możliwej konstrukcji: jesteś butny $i$ arogancki, ale odnosi te słowa do atrybutu oponenta (jego władzy), unikając bezpośredniego ataku na osobę. Stawia się przy tym w pozycji rzecznika interesów owych „najsłabszych grup”, co pozwala połączyć deprecjację z pozytywną autoprezentacją. $\mathrm{Na}$ uwagę zasługuje również forma adresatywna: panie Jarostawie. Użycie imienia zamiast naturalniejszego w tym kontekście tytułu sugeruje zmniejszenie oficjalności kontaktu, a nawet życzliwość wobec rozmówcy. Może to stanowić dodatkowe zabezpieczenie przed posądzeniem o brutalność i ostrość wypowiedzi.

Inny sposób wprowadzenia potocznej inwektywy wykorzystał Kaczyński, odpowiadając na zarzut Kwaśniewskiego: To, co czasem się zdarzy po naszej stronie, powtarzam, czasem, to jest $w$ ogóle catkowicie nieporównywalne, to jest jakiś tam strzat z wiatrówki w porównaniu z ogniem artyleryjskim takim, niebywatego wręcz nawatu zwyktego cham-

9 J. Bralczyk, O języku polskiejpolityki lat osiemdziesiątych i dziewięćdziesiątych, Warszawa 2003, s. 70. 
stwa. Określenie chamstwo nie zostało przypisane wprost żadnej postaci ani grupie czy jej działaniom. Dopiero kontekst pozwala wywnioskować, że chodzi o ludzi związanych z oponentem, o jego środowisko. Taki niejednoznaczny adresat pozwala na wzmocnienie inwektywy (niebywaty wręcz nawat), obudowanej dodatkowo militarnym porównaniem. Siła emocjonalna tej wypowiedzi jest duża, ale życzliwie nastawiony widz będzie skłonny wybaczyć dosadny język, bo motywować go może oburzenie ripostującego na zarzut, który jest, jego zdaniem, nadużyciem.

Innym dość bezpośrednim mechanizmem deprecjacji jest etykietkowanie, czyli zaliczanie twierdzenia przeciwnika (lub jego samego czy jego działań) do negatywnej kategorii pojęć. Zabieg ten, analizowany najczęściej w kontekście propagandy totalitarnej, jest często także dziś spotykany w języku polskiej polityki.

Klasycznym dziataniem $w$ zakresie perswazji politycznej jest przydawanie bytom i ludziom (najczęściej przeciwnikom) stygmatyzujacych etykietek, w których przewaga konotacji nad denotacja ma wywotać odpowiednie ( $w$ przekonaniu nadawcy) nastawienie do tak nazywanego obiektu. [...] Dzisiejsze etykietki sa zaledwie bronia w polemikach, ale upraszczają rzeczywistość i korzystając $z$ atrakcyjnej formuty nacechowania i skrótu, nie sa przecież bronia etycznie catkiem usprawiedliwiona. Produkują agresję zarówno u tych, którzy je chętnie stosują, jak i u tych, których określają ${ }^{10}$.

Etykietkowanie unieruchamia więc przeciwnika, jednoznacznie go kwalifikując, i odbiera możliwość merytorycznej dyskusji. Ten negatywnie oceniany zabieg jest jednak na tyle atrakcyjny perswazyjnie, że nadawcy tekstów politycznych chętnie się do niego odwołują.

Co ciekawe, w analizowanych debatach pojawia się on rzadko, co zdaje się potwierdzać tezę, że chęć zachowania pozytywnego wizerunku ogranicza stosowanie technik jednoznacznie dyskredytujących. Nie znaczy to jednak, że rozmówcy rezygnują z niego całkowicie. Tusk tak zwraca się np. do Kwaśniewskiego: Obawiam się o pana, jak pan wróci do swoich towarzyszy z LiDu. Etykietką jest tutaj słowo towarzysz, przy czym zyskuje ono negatywne konotacje jedynie w kontekście politycznym. Nadawca wykorzystuje skojarzenie z partią, której członkowie tak się do siebie zwracali, i zakłada, że widz oceni ją negatywnie, a następnie przeniesie tę ocenę na LiD. Sugeruje przy tym personalną ciągłość między obiema partiami.

W tej samej debacie, chwilę później, Tusk tak charakteryzuje działalność Kwaśniewskiego: Pan cate swoje doroste życie budowat socjalizm. Czy wtedy, przed 89 rokiem, w partii wiadomej, i wtedy, kiedy byt pan przez dziesięć lat prezydentem. W tej wypowiedzi użyto etykietki socjalizm; jak może oczekiwać nadawca, wielu Polakom będzie się on kojarzył negatywnie. Na tyle negatywnie, że nie będą się oni wdawać $\mathrm{w}$ analizy znaczeniowe i nie dostrzegą manipulacji znaczeniem słowa (nazwanie socjalizmem różnych zjawisk i zatarcie różnicy między nimi). Skojarzenie interlokutora z socjalizmem ma go więc deprecjonować. Nadawca wzmacnia oddziaływanie umniejszające przywołanej etykietki przez zestawienie jej z wyrażeniem partia wiadoma. Używanie takich określeń, nie nazywających wprost, a jedynie sugerujących, ma

$10 \quad$ Tamże..., s. 77. 
wzmocnić więź nadawcy z audytorium, które bez problemu odszyfruje niedomówienie, co potwierdzi wspólnotę wiedzy. (Warto przy tym zauważyć, czego nadawca, zdaje się, nie do końca jest świadom, że ten ostatni zabieg jest właśnie charakterystyczny dla języka polityki z czasów, które ocenia negatywnie i które chce powiązać z interlokutorem. To dla nowomowy bowiem znamienne były określenia typu wiadome kregi, określone grupy).

O tym, że użyta etykietka ma swoją moc, świadczy reakcja rozmówcy: Dla mnie stowo socjalista nie jest obraźliwe. Tym zaprzeczeniem paradoksalnie potwierdza, iż rozumie, że dla nadawcy takim ono jest, a jednocześnie próbuje rozbroić etykietkę. To zresztą sprytny zabieg, bo słowo socjalizm zostało w ripoście zastąpione socjalistą, a negatywne konotacje wiązane z tym ostatnim wydają się w polszczyźnie dużo słabsze. Do podobnych skojarzeń odwołuje się Kaczyński, zwracając się do Kwaśniewskiego: I tym bardziejpowinien siępan pilnowaćjako byty PZPR-owiec.

Kiedy wśród użytych określeń nie pojawia się inwektywa czy etykietka, politycy pozwalają sobie czasem na przypisywanie negatywnych charakterystyk wprost, jak np. Kaczyński wobec Tuska: Ma pan krótka pamięć, panie przewodniczący czy Tusk wobec Kaczyńskiego: Pan może deklarować nigdy z LiDem, nigdy z Samoobrona, nigdy z SLD, a dla wtadzy zrobi pan wszystko. Można powiedzieć, że sytuacja debaty przedwyborczej usprawiedliwia formułowanie takich jawnych ocen. Są to jednak przypadki rzadkie. I tutaj częściej działa zasada zabezpieczenia przed posądzeniem o agresję językową i brak taktu. Zastosował ją np. Kaczyński, zwracając się do Kwaśniewskiego w następujący sposób: Panie prezydencie, po pańskich ostatnich gafach, jak to pan jest taskaw określać, no pan jako krytyk czegokolwiek, co sięw Polsce robi w polityce zagranicznej, jest, tagodnie mówiąc, catkowicie niewiarygodny. Uwzględnione tu zostały wszelkie wymogi etykiety językowej, wypowiedź ma charakter stonowany. Nadawca prezentuje się jako osoba wyważona, rozważnie dobierająca słowa, unikająca brutalnych określeń. Jednocześnie jednak grzeczność językowa jest tu wyrazem ironii. Jak to pan jest taskaw określać jest wyrażeniem zawierającym pewien „nadmiar” kurtuazji, a jednocześnie sugeruje, że owe gafy sam nadawca nazwałby zupełnie inaczej. W podobnej funkcji użyte zostało sformułowanie tagodnie mówiąc, sygnalizujące, że tylko takt nie pozwala określić tej „niewiarygodności” ostrzej.

Zbliżonąstrategię zastosował zresztą chwilę później w tej samej debacie Kwaśniewski: Pan premier jest taskaw mówić o tej polityce na kolanach czy polityce partii biatej flagi i to jest, jak powiedziatem, wyjątkowo nierozsadne, żeby nie powiedzieć wręcz skandaliczne. Pojawia się tu wprawdzie mocniejszy epitet (skandaliczne), ale oceniany jest nie sam interlokutor, lecz sformułowana przez niego opinia, przy zachowaniu wszelkich wymogów etykiety językowej wobec oponenta. Ponadto bardziej nacechowane słowo zostaje wprowadzone przy użyciu określenia zabezpieczającego żeby nie powiedzieć, jakby nadawca sam wahał się przed jego użyciem.

Zdystansowanie się do własnego określenia zaprezentował też Kaczyński, zwracając się do Kwaśniewskiego: Ta dyskusja [...] pokazata przede wszystkim niezmienność pewnych postaw, zwtaszcza pańskiej postawy. Pan jest tutaj catkowicie nieuleczalny, jeśli wolno użyć takiego określenia. 
W nieco inny sposób przemycił zdecydowanie negatywną ocenę Kwaśniewski, odpowiadając Kaczyńskiemu na zarzut, że w polityce zagranicznej załatwił tylko te sprawy, które załatwiłby każdy: To jest [...] brutalna ocena, z którą sięnie zgadzam, ale mógtbym równie brutalnie powiedzieć: pan za to zepsuje tylko to, co pan potrafi zepsuć na tym świecie. Po pierwsze, stwierdza się tu coś o przeciwniku w czasie przyszłym, co czyni to stwierdzenie niesprawdzalnym, a więc nie można mu zarzucić fałszu. Po drugie, nadawca zaznacza, że ma świadomość ostrości własnej wypowiedzi (a więc zna zasady grzeczności językowej), pozwala sobie jednak na nią, bo to rozmówca go sprowokował, to on narzucił agresywny ton. Przy okazji sformułować można jeszcze jeden zarzut wobec przeciwnika - brutalność. Nadawca stawia się więc w pozycji ofiary ataku, na który zmuszony jest zdecydowanie zareagować. Dodatkowo wypowiedź ta zabezpieczona jest użyciem trybu warunkowego. Formalnie przecież nadawca niczego złego o adwersarzu nie stwierdza, a jedynie mógtby stwierdzić.

Bardzo skuteczną, choć uważaną za manipulacyjną, metodą deprecjonowania interlokutora jest umieszczenie negatywnego sądu w presupozycji. Ocena przekazywana jest tutaj w sposób niejawny, co pozwala na zawoalowanie intencji deprecjacji i chroni przed wspomnianym już niebezpieczeństwem niekonsekwencji w budowie własnego wizerunku. Inną korzyścią jest fakt, że przy interpretacji presupozycji uwaga stuchacza, świadoma jego refleksja ogniskuje się bardziej na tym, co się $w$ zdaniu stwierdza, niż na tym, co się presuponuje, dlatego też określenia typu „Przejrzeliśmy te ich ciemne machinacje" [...] wsiakają w świadomość czytelnika czy stuchacza jako określenia pejoratywne, [...] nie napotykajac na refleksje i sprzeciw odbiorcy ${ }^{11}$.

Tak przemycona ocena trudno poddaje się weryfikacji i zostaje najczęściej przyjęta bez krytycznej refleksji. Jednocześnie odwołując się do presupozycji, niejako wywołuje się partnera do odpowiedzi i narzuca płaszczyznę rozmowy. Zaatakowany musi się do presuponowanej treści jakoś ustosunkować, np. przez protest lub sprostowanie, i w ten sposób traci czas, a nierzadko dekoncentruje się i gubi wątek.

Stosunkowo prostym mechanizmem wprowadzenia presupozycji jest pytanie, na które nie oczekuje się odpowiedzi. Pod pozorem pytania przemyca się rozmaite założenia i oceny. Pozornie zwracając się do rozmówcy, podsuwa się obserwatorom jakąś tezę. W analizowanym materiale znaleźć można sporo przykładów zastosowania tego chwytu, wśród nich słowa Tuska do Kaczyńskiego: Dlaczego pan mówi nieprawdę?, Czy ma pan odwage patrzeć teraz w twarz Polakom i przyznać się do tej zupetnie upiornej liczby 300 milionów ztotych? (Chodzi o pieniądze przeznaczone na utrzymanie dwóch kancelarii - prezydenta i premiera.) i Kwaśniewskiego do Kaczyńskiego: Czemu pan nie potrafi powiedzieć dobrego stowa o innym cztowieku? Dlaczego uważa pan, że wszystko zaczęto sięna panu i skończy się na panu? Rzeczywistymi adresatami tych wypowiedzi nie są rozmówcy. Nie chodzi o to, by usłyszeć odpowiedź. Trudno sobie przecież wyobrazić reakcję typu: Mówię nieprawdę, ponieważ... Prawdziwym celem tych niby-pytań jest przypisanie interlokutorowi odpowiednio - nieprawdomówności, rozrzut-

11 Z. Leszczyński, Wyraz postawy wartościującej w języku naturalnym, [w:] Wartości w jezzyku i tekście, red. J. Puzynina, J. Anusiewicz, Wrocław 1991, s. 47, Jezyk a Kultura, t. 3. 
ności, nieżyczliwości i egocentryzmu. To właśnie ten przekaz ma odczytać widz, ta ocena ma pozostać w jego pamięci. W opisywanych przypadkach presupozycja nie jest zresztą ukryta głęboko i odczytanie założonej intencji nie wymaga szczególnego wysiłku interpretacyjnego.

Presupozycję wprowadzić można także w zdanie twierdzące, przy czym mechanizm przemycania deprecjonującej oceny jest właściwie ten sam. Schemat ten wykorzystał np. Tusk w debacie z Kaczyńskim: Ja postanowitem przypomnieć jedna scene, żeby Polacy zrozumieli, dlaczego tak trudno sie z panem rozmawia, dlaczego pan zawsze chce kogoś zdominować. W tym przykładzie rzeczywisty adresat wypowiedzi przywołany jest zresztą wprost, mimo że formalnie jest ona skierowana do rozmówcy. Chęć dominacji przypisywana przeciwnikowi przedstawiona jest tu jako oczywista, niepodlegająca dyskusji. Zastanawiać można się jedynie nad tym, dlaczego on taką cechę posiada.

Ciekawy sposób obudowania presupozycji wykorzystał Tusk, zwracając się do Kwaśniewskiego: Przez litość nie będę tu cytowat opinii na temat bogactwa i pazerności środowiska lewicy, wypowiadanej nie przeze mnie, ale przez pana wieloletniego towarzysza partyjnego. Zdeprecjonowanie przeciwnika odbywa się tu na kilku poziomach, a zabezpieczenie nadawcy jest podwójne. Najważniejszą oceną, przekazaną presupozycyjnie, jest bogactwo i pazerność środowiska lewicy, a więc grupy reprezentowanej przez oponenta. Dodatkowo na początku nadawca odwołuje się do litości, sytuując rozmówcę w pozycji niższej, godnej pożałowania. Tusk wprowadza przy tym pewien sąd, formalnie się od niego odżegnując, w myśl zasady „nie powiem tego, co powiem”, a zabieg ten pozwala mu dodatkowo zdystansować się do kontrowersyjnego sformułowania. Ponadto przedstawia się on nie jako autor wyrażonej opinii, ale jedynie jej przekaziciel, gdyż sformułowana została przez kogoś innego i to ten ktoś bierze za nią odpowiedzialność. Co więcej, autor cytowanej opinii należy do grona zwolenników oponenta, co z jednej strony zwiększa jej wiarygodność, a z drugiej sugeruje widzowi nie najlepszą ocenę całego środowiska, jako nieuczciwego i w dodatku cynicznego. To ostatnie widz musi jednak wywnioskować samodzielnie, odwołując się do kontekstu wypowiedzi i wspólnej wiedzy o świecie. Prowadzi to do kolejnego sposobu ukrytego wyrażania własnych sądów, umożliwiającego przekazywanie opinii kontrowersyjnych, za które nadawca nie do końca jest gotów przyjąć pełną odpowiedzialność: implikatury.

W implikaturze deprecjacja przekazywana jest nie w samej wypowiedzi, ale w wynikających z niej wnioskach. Odbiorca na podstawie kontekstu, sytuacji albo wspólnej wiedzy musi sobie wydedukować pewną treść. Chodzi więc o sprytne naprowadzanie na pożądane wnioski, które należy sobie dopowiedzieć, aby uspójnić i uzupełnić wypowiedź, bez tego uzupełnienia niejasną.

Implikatury wartościujące negatywnie są stosunkowo łatwo interpretowane dzięki zasadzie, którą Aleksy Awdiejew nazwał warunkiem „złej woli” mówiącego.

Warunek „ztej woli" mówiacego ma charakter pragmatyczny i jest zaktadany zawsze, kiedy mamy do czynienia z sugerowaniem wartości czegoś nie wprost. Można tu przyjąć następująca zasadę: mówienie pozytywne o kimś/czymś nie wymaga sugerowania, może 
i zazwyczaj ma formę bezpośrednia. Z kolei sugerowanie czegoś za pomoca implikatur jest zazwyczaj znakiem tego, iż sugestia ma charakter negatywny ${ }^{12}$.

Mimo ukrycia umniejszającej oceny nadawca w zasadzie nie ryzykuje więc, że nie zostanie ona odpowiednio odczytana. Asekuruje się przy tym, gdyż z kontrowersyjnej implikatury łatwo się wycofać, stosując taktykę „przecież ja tego nie powiedziałem”. W końcu negatywna ocena nie zostaje sformułowana wyraźnie. I wreszcie: odczytanie implikatury jako leżącego u podstaw wypowiedzi założenia wymaga aktywizacji wspólnej wiedzy nadawcy i odbiorcy i tym samym istnienie tej wspólnoty potwierdza, co jest kolejną retoryczną korzyścią wynikającą z zastosowania tego środka.

A oto kilka przykładów zastosowania implikatury (choć w analizowanym materiale pojawia się ich więcej).

Tusk do Kwaśniewskiego: Wejście do strefy euro to sq ważne sprawy, to nie jest uśmiech i makijaż. Nadawca tej wypowiedzi sugeruje, że oponent więcej uwagi poświęca wizerunkowi niż rozwiązywaniu problemów i nie ma świadomości powagi sytuacji. Wykorzystany został przy tym obraz mężczyzny z makijażem, który, jak można założyć, wielu odbiorcom będzie się kojarzył negatywnie.

Kaczyński do Tuska: My trzymamy z dala od wtadzy Platformę Obywatelska, LiD, czyli sojuszników, i to jest najlepsza walka o tanie państwo. Wypowiedź ta ma nasunąć wniosek, że Platforma i LiD dążą do „drogiego państwa”, a negatywnie nastawiony do wskazanych ugrupowań odbiorca może także (choć nie jest to już sugestia konieczna do poprawnego zinterpretowania tego zdania, raczej konsekwencja podsuniętego kierunku myślenia) wnioskować, że do gospodarowania publicznymi pieniędzmi przez te partie można mieć zastrzeżenia. W wypowiedź tę została zresztą także wpleciona presupozycja, że Platforma i LiD to sojusznicy, która również ma służyć zdyskredytowaniu Tuska w oczach części elektoratu.

Kwaśniewski: Lewica rozpoczyna w tej chwili swój marsz. Tusk: Niech pan nie straszy, panie prezydencie. $\mathrm{Z}$ riposty Tuska należy wnioskować, że umacnianie się lewicy grozi niebezpiecznymi konsekwencjami, jest czymś, czego należy się obawiać.

Kaczyński do Kwaśniewskiego: To panu powie każdy ekonomista. Radzę panu z ekonomistami porozmawiać. Pozorna rada Kaczyńskiego jest w gruncie rzeczy sugestią, że rozmówca nie ma pojęcia o ekonomii, a więc nie powinien zabierać głosu w sprawach, na których się nie zna, bo jego opinie w tym względzie nie są miarodajne.

Po słowach, że już w czasach Okrągłego Stołu był bardzo ważny, Kwaśniewski odpowiedział Kaczyńskiemu: Bardzo inteligentny bytem, co Kaczyński zripostował słowami: Ja nie zauważytem, żeby ten system dobierat wedtug inteligencji. Wprost wyrażona tu została jedynie subiektywna deklaracja, że nadawca czegoś nie zauważył, w istocie jednak chodzi o to, by widz wyprowadził samodzielnie wniosek na temat kwalifikacji, które zadecydowały o pełnieniu przez zaatakowanego ważnej roli przy Okrągłym Stole. Skoro nie była to inteligencja, musiały to być inne cechy promowane przez ten system, jakie widz musi sobie dopowiedzieć na podstawie własnej wiedzy o świecie (a właściwie tego

12 A. Awdiejew, Wartościowanie wymuszone a szacunek dla odbiorcy w dyskursie politycznym, [w:] Język polityki..., s. 51. 
jej wycinka, który wiąże się z oceną funkcjonariuszy tego systemu) oraz znajomości przekonań atakującego. Wnioski powinny być deprecjonujące dla Kwaśniewskiego.

Jedną ze sprawdzonych metod deprecjonowania przeciwnika jest odwołanie się do różnych form komizmu. Skutecznie stosowane techniki komiczne narażają na dezaprobatę oraz utratę poważania i wiarygodności. Uczestnicy polskich publicznych debat i sporów coraz chętniej i odważniej korzystają z tego narzędzia, także w walce wyborczej. Kazimierz Ożóg dostrzega nasilanie się elementów tego zjawiska i nazywa je karnawalizacją polskich kampanii wyborczych ${ }^{13}$. Ich uczestnicy sięgają do różnych form komizmu, od łagodnego, nietendencyjnego humoru (najczęściej w celach autoprezentacyjnych) po zjadliwy sarkazm. Niektórzy nie stronią od prymitywnych form ośmieszania przeciwnika, takich jak wyśmiewanie ułomności fizycznych, złośliwe przekręcanie nazwisk, wulgarne dowcipy itp.

W sytuacji debaty telewizyjnej, a więc bezpośredniego starcia przeciwników, wykorzystywane są raczej tendencyjne formy komizmu; śmiech jest tu skierowany przeciwko komuś. Celem jest narzucenie publiczności postawy lekceważenia wobec oponenta, wykazanie, że prezentowane przezeń poglądy nie zasługują na poważne potraktowanie, a on sam jest postacią pozbawioną powagi i wiarygodności, a co za tym idzie - niegodną zaufania. Odbywa się to przy tym w formie atrakcyjnej dla widza, który ma możliwość rozładowania napięcia towarzyszącego obserwowanej konfrontacji przez śmiech i osiąga satysfakcję z rozszyfrowania dowcipu. Poza tym przez komiczne pomniejszenie rangi osoby publicznej widz odczuwa nagły wzrost poczucia własnej wartości, co może być sposobem na rozładowanie frustracji wynikającej z własnych niepowodzeń. Wszystkie te czynniki powodują, że na zasadzie swoistej „wdzięczności” pozytywnie ustosunkowuje się on do tego, kto mu taką okazję stworzył. Ponadto, jak zauważa Mirosław Karwat, taktyka prześmiewcza ma charakter intensywny, wydajny [...], stwarza wrażenie "luzu”, a więc otwartości, pomystowości, inteligencji, a nawet wrażenie - ztudzenie (spotegowane zastosowaniem dystansu w chwytach satyrycznych), że ten, kogo stać na taki dystans, jest poniekąd bezstronny [...]. Stąd może wynikać nawet iluzja, że ta dowcipna strona sporu broni po prostu zdrowego rozsądku, rozumu, adekwatności prawdy, autentyzmu [...], a nie wtasnych korzyści, ambicji i swojej ideologii ${ }^{14}$.

Przed śmiechem trudno się obronić.

Trudność obrony wiąże się przede wszystkim z tym, że reakcja na śmieszność prawie zawsze jest spóźniona. Najpierw ludzie sięśmieja (odbierając swój śmiech jako reakcjespontaniczna i dobrowolna, a nie sprowokowana i wymuszona) i częściowo przynajmniej „wchtaniaja jad" (choćby na zasadzie „cośw tym jest”), a dopiero potem - zoporem zmuszani sa

13 Prowadzac badania nad przemianami wspótczesnej polszczyzny, obserwuje od roku 1989 polskie kampanie wyborcze i zauważam w nich znaczacy wzrost karnawalizacji. Można zatem wnioskować, że przekonywanie odbiorców za pomoca zabawy, humoru, dowcipu ma w opinii przygotowujacych kampanię duży stopień skuteczności. K. Ożóg, Karnawalizacja polskich kampanii wyborczych, [w:] Humor i karnawalizacja we wspótczesnej komunikacji językowej, red. J. Mazur, M. Rumińska, Lublin 2007, s. 261, Język, Kultura, Spoteczeństwo.

14 M. Karwat, O ztośliwej dyskredytacji. Manipulowanie wizerunkiem przeciwnika, Warszawa 2007, s. 323 . 
do zapoznania się z protestem, sprostowaniem. Ale prostowanie dowcipu czy jego puenty to dziatanie, które samo w sobie jest równie śmieszne jak powtórne ttumaczenie dowcipu osobie, która go nie zrozumiata ${ }^{15}$.

W analizowanym materiale oponenci także odwoływali się w celach deprecjacyjnych do komizmu tendencyjnego. Ich komiczne wypowiedzi cechowało różne nasilenie agresji, nie pojawiły się w nich jednak najbardziej niewybredne formy ośmieszania. Mimo swoistego kamuflażu, jaki daje dowcip, i tutaj zadziałały więc wymogi etykiety językowej i obawa przed negatywnymi konsekwencjami dla własnego wizerunku, jakie mogłoby spowodować użycie zbyt ostrych, bezpośrednich i jednoznacznych środków językowych.

W'sód stosowanych przez rozmówców sposobów ośmieszania przeciwnika pojawia się między innymi infantylizacja, czyli językowa próba sprowadzenia go do pozycji dziecka, a więc podrzędnej. I tak np. Kaczyński zwraca się do Tuska: Panie... Donaldzie. Ja wtaśnie nie wiem, panie Donaldku, Donaldeczku... Deprecjonujący jest tu sam zwrot do adresata. Użycie zdrobnienia, którym w poważnej dyskusji nie powinno się zwracać do polityka (zabraniają tego zasady etykiety językowej), potraktowanie go jak dziecka, ma odebrać powagę i znaczenie rozmówcy. Imię Donald trudno przy tym ulega zdrobnieniu i jego formy dyminutywne mogą rzeczywiście mieć dla widza zabawny wydźwięk.

Z kolei Kwaśniewski tak określa stanowisko Tuska: Tak naprawde wy się niewiele różnicie, będę starat się tę tezę udowodnić. Czasami zachowujecie się trochę jak poktóceni koledzy, ale z tej samej piaskownicy (chodzi o PiS i PO.) Porównanie liderów partii do chłopców bawiących się w piaskownicy jest umniejszające, odbiera powagę zarówno im, jak i ich działaniom.

Także Tusk odwołuje się do określeń opisujących dziecięce zachowania, zwracając się do Kaczyńskiego słowami: Chciatbym, żeby pan wreszcie zrozumiat, że dobra polityka zagraniczna nie polega na strojeniu groźnych min i dąsaniu się. Dąsanie się i strojenie min to raczej niedojrzała taktyka osiągnięcia czegoś. Znamienny jest tu także dobór słów. „Dąsa się” i „stroi miny” raczej osoba o niewielkiej powadze, której pretensje traktuje się co najwyżej z pobłażaniem, a nie serio. Kojarzy się to ponadto z dziecięcym kapryszeniem i bezradnością, a skojarzenie to może skutecznie złamać spójność wizerunku poważnego polityka.

Tonację komiczną można także uzyskać przez wprowadzenie dowcipu lub anegdoty, jak to zrobił na przykład Tusk w polemice z Kaczyńskim: Zacytuje dowcip: Obiecaliście 3 miliony mieszkań, a sa mieszkania za 3 miliony. Nadawca posłużył się tutaj dowcipem opartym na grze słownej. Oprócz korzyści wynikających z rozbawienia audytorium zyskał jeszcze coś: obiektywizację własnej oceny, jej potwierdzenie. Przedstawił się bowiem nie jako autor dowcipu, ale jedynie ten, kto go cytuje, sugerując, że przytacza powszechną opinię, zawartą w krążącym dowcipie. Anonimowość jego autorstwa odebrana może być jako wyraz krytycznego głosu opinii publicznej, a nie subiektywna ocena nadawcy.

15 Tamże..., s. 326. 
Celom deprecjacyjnym może także służyć wypowiedź o charakterze ironicznym. Pojawienie się w analizowanym materiale licznych przykładów użycia tego zabiegu potwierdza tezę, że jest to jeden z bardziej powszechnych (i skutecznych) sposobów prowadzenia sporów politycznych ${ }^{16}$. Mechanizm ironii zakłada wyrażanie niewprost znaczenia sprzecznego z dosłownym sensem zdania. Jest ono rozpoznawalne dla odbiorcy dzięki różnorakim sygnałom, które mogą mieć charakter tekstowy (np. cudzysłów, słowa typu „mniemany”, wewnętrzne sprzeczności tekstu itd.) lub pozatekstowy (kontekst, ton głosu, mimika). Przyjmujac tekst za ironiczny, zaktadamy konieczność pojawienia się wartościowania, które jest pragmatyczna funkcja ironii. Tresśc jawna, jaka zawiera wypowiedź o charakterze ironicznym, jest pozytywna, ale odsyta do treści ukrytej, negatywnej ${ }^{17}$. Atrakcyjność i skuteczność ironii polega na tym, że pozwala się ona domyślać czegoś więcej, niż zostało dosłownie powiedziane. Jej odczytanie wymaga współdziałania odbiorcy, angażuje wspólną wiedzę nadawcy i odbiorcy, wzmacniając wspólnotę między nimi, także przez wskazanie wspólnego wroga. Ironia pozwala również na asekurację przecież nadawca niczego złego w sensie dosłownym nie powiedział - a zarazem chroni przed przeciwnikiem, ponieważ replika wobec ironii jest bardzo trudna (chyba że jest to również replika ironiczna).

Ironia może przybrać postać przygany przez pochwałę. Środek ten wykorzystał na przykład Tusk w debacie z Kaczyńskim: Zaskoczyt mnie pan wtasna odwaga, pytajac o cięcia budżetowe. Ja mam pytanie, ile kosztuje utrzymanie wtadzy. Pozornie mamy tu do czynienia z pochwałą cechy charakteru oponenta (wyrażoną zresztą presupozycyjnie).Znając relację między dyskutantami, a także mając świadomość charakteru rozmowy, widz będzie się jednak do tego komplementu odnosił podejrzliwie. Jego wątpliwości uzasadni dalszy ciąg wypowiedzi, z którego wnioskować powinien następująco: jeśli pytanie o cięcia budżetowe ma być wyrazem odwagi, to znaczy, że jest to temat trudny, którego bezpieczniej byłoby nie poruszać. Zapewne więc jest to słaba strona oponenta. Ten tok rozumowania potwierdza końcowe pytanie, które przecież nie służy temu, by uzyskać odpowiedź, ale by zasugerować, że utrzymanie władzy kosztuje za dużo. Pod pozorem pochwały kryje się zarzut nadmiernego wydawania publicznych pieniędzy.

Również Kaczyński, zwracając się do Tuska, zastosował podobny chwyt: Ja nawet pana lubię za to jako osobę, bo pan jest bardzo konsekwentny w swoich poglądach, tylko że to sa straszne poglądy. Początek tej wypowiedzi brzmi jak wyrażenie sympatii dla rozmówcy, jej właściwy sens jest jednak czytelny dopiero po zastosowaniu interpretacji ironicznej. Pierwszym sygnałem ironii jest modalizator nawet, który wskazuje, że lubienie przeciwnika nie jest czymś oczywistym ani łatwym (a więc - w domyśle - raczej lubić się go nie powinno). Potwierdzeniem ironicznego kierunku interpretacji jest ocena zawarta w ostatniej części analizowanego zdania, która przez sprzeczność z częścią pierwszą pokazuje, że wyrażona na wstępie pochwała była pozorna.

$\mathrm{Na}$ sprzeczności między sensem różnych części wypowiedzi oparty jest także zabieg zastosowany przez Tuska w rozmowie z Kwaśniewskim: Panie prezydencie, pan ma

16 Por. G. Habrajska, Wykorzystanie ironii do walki politycznej, [w:] Jezzyk polityki..., s. 57-58.

17 Tamże, s. 67. 
rzeczywiście perspektywe imponujaca. Ja pytatem, o ile wzrosnać ma ewentualnie udziat doptat do wspólnej polityki europejskiej, a pan o umieraniu i o Chinach. Również tę wypowiedź rozpoczyna pozorny komplement, podważony następnie przez rozwinięcie kwestii. Zaistniała sprzeczność jest sygnałem, że należy szukać innej interpretacji: intencją nie jest pochwała, ale pomniejszenie oponenta przez wskazanie, że nie potrafi merytorycznie dyskutować.

Innym wykorzystywanym w debatach mechanizmem wprowadzenia ironii jest ironiczna niekompetencja. Polega ona na tym, że nadawca pozornie sytuuje się w roli osoby, która nie rozumie działań czy intencji przeciwnika. Zabieg ten ma jednak prowadzić do wniosku, że to właśnie te działania czy intencje są dziwaczne, niepojęte lub podejrzane. Taką interpretację potwierdza opis działań przeciwnika jako absurdalnych. Oto przykłady zastosowania tej taktyki:

Tusk do Kaczyńskiego: Jeśli dobrze zrozumiatem, chce pan budować mieszkania przez rozbijanie uktadów?

Kaczyński do Tuska (na zarzut o uległość wobec USA): Pan chce prowadzić wojnę!?

Sygnały ironiczności mogą pojawić się w tekście, często jednak jest ona czytelna tylko dzięki wspólnej wiedzy nadawcy i odbiorcy, która modyfikuje sens wypowiedzi. Tak jest w przypadku riposty Kwaśniewskiego w stosunku do Tuska, który domagał się odpowiedzi na pytanie, czy przeciwnik wie, jak krok po kroku założyć firmę: Ja panu powiem, jak krok po kroku zatożyć partię, jak przeprowadzić kampanię wyborcza, ja panu nawet kiedyśs powiem, jak wygrać wybory prezydenckie, krok po kroku. Widz, który wie, że Tuskowi nie udało się wygrać wyborów prezydenckich, bez trudu odczyta ironiczną uszczypliwość pod jego adresem. Kwaśniewski zyskuje jeszcze coś - udaje mu się odwrócić uwagę od problemu poruszonego przez oponenta i przenieść tego ostatniego na pozycję defensywną.

Dla jasności wywodu przedstawione mechanizmy deprecjacji analizowane były dotąd oddzielnie, jednak żywej wymiany zdań nie można ująć w proste schematy. Najczęściej bowiem rozmówcy łączą ze sobą w jednej wypowiedzi różne techniki. Za przykład niech posłuży wypowiedź Tuska skierowana do Kwaśniewskiego: Jest pan, jak to oni sami określili, raczej twarza (zresztą wspótczuje panu partnerów), raczej twarza niż mózgiem kampanii wyborczej. Po pierwsze, mamy tu do czynienia z obiektywizacją oceny. Nadawca mówi nie tylko we własnym imieniu, ale powołuje się na zdanie innych osób. Ci inni to przy tym sojusznicy rozmówcy, do reprezentowania których on sam się przyznaje, nie może więc podważyć ich opinii. Prowadzi to do wniosku: nawet twoi przyjaciele nie traktują cię poważnie. Cytowane zdanie deprecjonuje także osoby związane z interlokutorem, czyli grupę, do której on należy, przez wyrażenie współczucia. W tym wypadku można wątpić w szczerość wyrażonej intencji. Chodzi raczej o to, że współczuje się czegoś przykrego, niedobrego - współpracownicy zostali więc ocenieni w ten właśnie sposób. Ocena ta nie została przy tym sformułowana wprost, ale przy użyciu implikatury. Kolejny zastosowany zabieg to przywołanie potocznej metafory (twarzy i mózgu), która przez częstą powtarzalność w polszczyźnie medialnej jest powszechnie zrozumiała. Metafora sugeruje, że rozmówca nie ma realnego wpływu na wydarzenia, jest tylko symbolem, więc tak naprawdę nie trzeba się z nim liczyć. 
Połączenie technik zastosował także Tusk w wypowiedzi skierowanej do Kaczyńskiego: Niech pan mówi prawdę. Aż tak ztym premierem pan nie jest, żeby sztukować wszystko propaganda. W presupozycji pojawia się tutaj zarzut sztukowania wszystkiego propaganda, a sformułowanie aż tak ztym premierem pan nie jest implikuje, że może nie aż tak złym, ale złym na pewno.

Należy ponadto zwrócić uwagę, że deprecjacja przeciwnika jest w analizowanym materiale bardzo ściśle powiązana $z$ autoprezentacją. Wiele wypowiedzi pełni podwójną funkcję. Można założyć, że jeżeli ktoś wytyka przeciwnikowi jakieś zachowania bądź przypisuje mu pewne cechy, sugeruje jednocześnie, że są to zachowania i cechu mu obce - lub przynajmniej że w jego systemie wartości są one oceniane negatywnie. W niektórych wypowiedziach zestawienie negatywnych cech przeciwnika i pozytywnych nadawcy pojawia się wprost. Są one zbudowane na zasadzie kontrastu, tak jak replika Kwaśniewskiego skierowana do Kaczyńskiego: Moja polityka polega na dialogu, pańska polityka polega na opluwaniu i obrzucaniu.

Właśnie wymogi autoprezentacji mogą decydować o tym, że rozmówcy zdecydowanie częściej wybierają zawoalowane formy deprecjacji i wyraźnie unikają jawnej i bezpośredniej agresji. Dotyczy to także sytuacji, gdy jeden z uczestników zaczyna się denerwować czy oburzać. Nawet wtedy stara się jakoś złagodzić ton swojej wypowiedzi bądź ukryć się za wypowiedzią cudzą. Co ciekawe, wszyscy uczestnicy, choć reprezentują różny typ dyskursu politycznego, stosują w tym celu bardzo podobne techniki. Na podstawie analizowanego materiału nie można wskazać chwytów preferowanych przez któregoś z rozmówców - wszyscy trzej posługują się podobnym ich zestawem.

Mimo iż język polityki zasadniczo postrzegany jest przez odbiorców jako zbyt brutalny, przywołane debaty telewizyjne nie do końca uzasadniają taką opinię. Trudno oczywiście mówić o przyjaznej atmosferze rozmowy; wzajemna niechęć jest często wyczuwalna, ale nie jest ona wyrażana dosadnie. Oprócz wymogów autoprezentacji owo złagodzenie tonu wymuszać może także sama sytuacja debaty telewizyjnej. Trudniej jest bowiem zaatakować obraźliwą uwagą przeciwnika, z którym staje się twarzą w twarz, niż wygłaszać złośliwe komentarze na jego temat, kiedy nie ma on możliwości riposty. Dlatego też, choć w innych typach wypowiedzi politycy nie stronią od ostrych, brutalnych opinii i niewybrednych epitetów, obecność oponenta w studiu zdaje się powstrzymywać ich od użycia tak agresywnych środków. Była już mowa o tym, że analizowane debaty zapowiadane były w mediach jako wydarzenia doniosłe, o szczególnej randze. Uczestniczący w nich politycy zdawali się mieć świadomość tego, że wymagają one pewnej oficjalności zarówno w zachowaniu, jak i w języku. Starali się więc pokazać, że umieją stanąć na wysokości zadania i dostosować się do powagi wydarzenia.

\section{BIBLIOGRAFIA}

Awdiejew A., Wartościowanie wymuszone a szacunek dla odbiorcy w dyskursie politycznym, [w:] Jezyk polityki a wspótczesna kultura polityczna, red. J. Anusiewicz, B. Siciński, Wrocław 1994, Jezyk a Kultura, t. 11 
Bralczyk J., O jezyku polskiejpolityki lat osiemdziesiątych i dziewięćdziesiątych, Warszawa 2003.

Bralczyk J., Mosiołek-Kłosińska K., Zwyczaje nominacyjne w polityce - autoidentyfikacja i stygmatyzacja, [w:] Zmiany w publicznych zwyczajach jezykowych, red. J. Bralczyk, K. Mosiołek-Kłosińska, Warszawa 2004.

Fras J., Komunikacja polityczna. Wybrane zagadnienia gatunków i jezzyka wypowiedzi, Wrocław 2005, Acta Universitatis Wratislaviensis, nr 2766.

Grzegorczykowa R., Obelga jako akt mowy, „Poradnik Językowy” 1991, nr 5-6.

Habrajska G., Wykorzystanie ironii do walki politycznej, [w:] Jezyk polityki a wspótczesna kultura polityczna, red. J. Anusiewicz, B. Siciński, Wrocław 1994, Jezyk a Kultura, t. 11.

Kamińska-Szmaj I., Agresja jezykowa w życiu publicznym. Leksykon inwektyw politycznych 1918-1920, Wrocław 2007, Acta Universitatis Wratislaviensis, nr 2957

Kamińska-Szmaj I., Stowa na wolności. Jezzyk polityki po 1989 roku. Wypowiedzi, dowcip polityczny, stownik inwektyw, Wrocław 2001.

Karwat M., O ztośliwej dyskredytacji. Manipulowanie wizerunkiem przeciwnika, Warszawa 2007.

Kita M., Czy można nie manipulować? O audiowizualnej retoryce w dyskursie politycznym, [w:] Manipulacja w jezyku, red. P. Krzyżanowski, P. Nowak, Lublin 2004, „Czerwona Seria” Instytutu Filologii Polskiej UMCS, 18.

Kochan M., Pojedynek na stowa. Techniki erystyczne w publicznych sporach, Kraków 2005.

Kołodziejek E., Jezykowe środki zwalczania przeciwnika, czyli o inwektywach we wspótczesnych tekstach politycznych, [w:] Jezyk polityki a wspótczesna kultura polityczna, red. J. Anusiewicz, B. Siciński, Wrocław 1994, Jezzyk a Kultura, t. 11.

Korolko M., Sztuka retoryki. Przewodnik encyklopedyczny, Warszawa 1998.

Lakomy L., O chwytach erystycznych w polskich kampaniach wyborczych, [w:] Media a polityka, red. A. M. Zarychta, Ł. Donaj, Łódź 2007.

Leszczyński Z., Wyraz postawy wartościującej w jezyku naturalnym, [w:] Wartości w języku i tekście, red. J. Puzynina, J. Anusiewicz, Wrocław 1991, Jezyk a Kultura, t. 3.

Lewiński P. H., Neosofistyka. Argumentacja retoryczna w komunikacji potocznej, Wrocław 2012, Acta Universitatis Wratislaviensis, nr 3399.

Majewska M., Akty deprecjonujace siebie i innych. Studium pragmalingwistyczne, Kraków 2005, Pragmatyka i Semantyka Mowy. Studia i Analizy, 5.

Ożóg K., Jezzyk w stużbie polityki. Językowy ksztatt kampanii wyborczych, Rzeszów 2004.

Ożóg K., Karnawalizacja polskich kampanii wyborczych, [w:] Humor i karnawalizacja we wspótczesnej komunikacji jezzykowej, red. J. Mazur, M. Rumińska, Lublin 2007, Jezyk, Kultura, Spoteczeństwo.

Peisert M., Formy i funkcje agresji werbalnej. Próba typologii, Wrocław 2004, Acta Universitatis Wratislaviensis, nr 2580.

Perelman Ch., Imperium retoryki. Retoryka i argumentacja, przeł. M. Chomicz, red. nauk. R. Kleszcz, Warszawa 2004.

Piontek D., Tabloidyzacja dziennikarstwa, [w:] Polubić dziennikarstwo, red. S. Zakrzewski, Poznań 2009.

Rittel S. J., Komunikacja polityczna. Dyskurs polityczny. Jezyk w przestrzeni politycznej, Kielce 2003. 
Schopenhauer A., Erystyka, czyli sztuka prowadzenia sporów, przeł. B. Konorski, Ł. Konorska, Warszawa 1986, Kulisy Polityki.

Szymanek K., Sztuka argumentacji. Stownik terminologiczny, Warszawa 2004.

Trysińska M., Jak politycy komunikuja sie ze swoimi wyborcami? Analiza jezzyka polityków na przyktadzie rozmów prowadzonych w telewizji polskiej oraz internecie, Warszawa 2004.

Dr Beata ZAJĄC, językoznawca, starszy wykładowca w Zakładzie Dziennikarstwa Instytutu Nauk Politycznych i Stosunków Międzynarodowych Uniwersytetu Jagiellońskiego. Zainteresowania badawcze związane są z problematyką retoryki, języka mediów i języka polityki. 